This PDF is a selection from an out-of-print volume from the National Bureau of Economic Research

Volume Title: International Policy Coordination and Exchange Rate Fluctuations

Volume Author/Editor: William H. Branson, Jacob A. Frenkel, and Morris Goldstein, editors

Volume Publisher: University of Chicago Press

Volume ISBN: 0-226-07141-3

Volume URL: http://www.nber.org/books/bran90-1

Conference Date: October 27-29, 1988

Publication Date: January 1990

Chapter Title: Equilibrium Exchange Rates

Chapter Author: Paul R. Krugman

Chapter URL: http://www.nber.org/chapters/c6948

Chapter pages in book: (p. 159 - 196) 


\section{Equilibrium Exchange Rates}

Paul R. Krugman

In the three years since the Plaza Accord the central bankers and finance ministers of the large industrial nations have come to a consensus in favor of exchange rate management. For better or for worse, it is now taken as a matter of course that the G-5 countries will at any given time form a collective view about the appropriate levels of nominal exchange rates, and make at least some effort to stabilize actual rates in the vicinity of those appropriate rates. Admittedly, what we have at the moment are "soft, quiet" rather than "loud, hard" 'target zones- that is, the zones are not publicly announced, nor is there great determination to defend them in the face of strong market pressures. That means that the zones are still a long way from a restoration of fixed rates. Yet in a muted form the de facto target-zone regime of the late 1980s does pose many of the traditional difficulties of any regime in which governments actively attempt to set the exchange rate.

The most basic of these difficulties is that of objective: what are the appropriate target exchange rates? At the time of the Plaza Accord, there was general agreement that the dollar needed to go lower (although only a few months before the U.S. administration had been claiming the strong dollar as a sign of successful economic policies). The question since has been where to stop. In a long-established fixed rate system, historical parities provide a natural focal point for policy coordination, and the problem of assessing equilibrium rates arises only when parity adjustment forces itself on reluctant policymakers. In the present situation, however, the effort to stabilize exchange rates requires making a judgement about appropriate levels more or less from scratch.

Paul R. Krugman is professor of economics at the Massachusetts Institute of Technology and a research associate of the National Bureau of Economic Research. 
The purpose of this paper is to discuss the issues raised in an effort to determine equilibrium exchange rates that may be appropriate targets for coordinated policies. I do not here attempt to address the question of whether it makes sense to have exchange rate targets at all, which would bring a number of additional issues into the picture; of course to the extent that equilibrium rates are found to be either hard to assess or unstable, this helps load the scales against trying to fix rates. The main focus, however, is on the hypothetical situation of a group of policymakers, such as the G-5 ministers, who have decided for better or worse to try to stabilize currencies around some agreed central rates. What considerations should enter into their choice of central rates? What problems of assessment should they be concerned about, and what methods are most likely to give reasonable answers?

The paper is in four parts. The first addresses the broad conceptual issue of what is meant by an equilibrium rate, and the reasons why target rates might differ from the current market rates on the eve of monetary agreement. The second part examines the extent to which equilibrium rates may be expected to show long-run trends; this issue is important both because an exchange rate regime needs somehow to accommodate such trends and because secular trends in equilibrium rates complicate the problem of guessing at the right rates during a transition to greater exchange rate stability. The third part examines the role of exchange rates in the process of narrowing international current account balances, reviewing and (I hope) settling some disputes that have arisen over the respective roles of fiscal and exchange rate adjustment in this process. The final part of the paper addresses the practical issues of assessment: how do we make a good guess at equilibrium exchange rates, and where might we go wrong?

\subsection{The Meaning of Equilibrium Exchange Rates}

The idea that one ought to attempt to calculate an equilibrium real exchange rate-with the implicit view that this rate may be different from the actual current rate-is itself controversial. In the years prior to the Plaza, thenUndersecretary Beryl Sprinkel repeatedly asserted that the equilibrium exchange rate is whatever the actual market rate is at this moment. His statement was of course true in the sense that the exchange market is pretty much continuously clearing. What advocates of some deliberate policy toward the exchange rate believe is not that there is literal disequilibrium in the market, but something more complex.

Briefly put, when we talk of the "equilibrium exchange rate" as something different from the current rate, we usually mean two things. First is that the equilibrium real exchange rate at some time in the future will be foreseeably different from today's real exchange rate. Second is that policy toward the nominal exchange rate can somehow facilitate the adjustment toward this future real exchange rate. Thus the question of whether it makes sense to 
calculate equilibrium real exchange rates as a basis for policy breaks into two subquestions: are there predictable and analyzable sources of real exchange rate shifts, and can nominal exchange rate policy facilitate such shifts?

\subsubsection{Sources of Shifts in the Equilibrium Real Exchange Rate}

\section{Real Shocks}

There is universal agreement on the principle that real events can change equilibrium real exchange rates, which are after all relative prices like any others. The sources of dispute are how large and how frequent such shocks are.

One possible source of shifts in equilibrium real exchange rates is the presence of secular trends due to differences in rates of technological change, differences in product mix, and so on. The potential presence of secular trends in the real exchange rate is of crucial importance and is given separate treatment below.

Aside from such long-run trends, the major source of real shocks to equilibrium exchange rates seems likely to be commodity-price shocks. For the G-5 countries, which are all primarily exporters of manufactures, such shocks cannot have the same importance that they do for primary exporters, but differences in resource position may mean that equilibrium rates are affected significantly nonetheless. In particular, a fall in the price of oil should presumably lower the equilibrium real exchange rate of self-sufficient Britain, while raising that of import-dependent Japan.

\section{Capital Flows}

A more controversial source of shifts in equilibrium real exchange rates is shifts in international capital flows.

Suppose that for some reason a country is the temporary recipient of substantial capital inflows. This might be because of an investment boom generated by technological change or resource discoveries, because of changes in tax laws, or because of a bulge in government deficits. Whatever the source, the capital inflows will normally be spent domestically to some important extent, raising the demand for nontraded goods produced domestically and also (perhaps) raising the relative price of a country's goods on world markets. To the extent that the capital flows are predictably temporary, there will be a prospective decline in the equilibrium real exchange rate. The relevance of this example to the U.S. case is of course obvious.

Why is this controversial? There are serious problems in deciding which capital flows are transitory and likely to trail off in the near future, and which are going to be long-term features of the landscape. For example, is Japan's current account surplus a temporary bulge, to be followed by a return to the much more modest surpluses of the pre- 1980 period, or is Japan going to be a twentieth-century equivalent of nineteenth-century Britain, consistently exporting several percentage points of GNP in capital for decades to come? A 
case can be made for either view. Also, economists can legitimately disagree about the substitutability of traded goods produced in different countries, and about the substitution between traded and nontraded goods within each country, leading to uncertainty about how large a real exchange rate change is needed to accommodate a given capital flow.

In addition to these legitimate controversies, however, there is also considerable sheer confusion about the relationship between real exchange rates and capital flows, the result of a failure by many economists to understand the meaning of the saving-investment identity. Like the long-run trend in exchange rates, this is a topic that requires further discussion and is given a section of its own.

\section{Nominal Shocks}

Most policymakers and many economists believe that real exchange rates can be temporarily pushed away from their long-run equilibrium values by nominal shocks, such as changes in monetary policy or, for that matter, pegging of nominal exchange rates at levels that imply disequilibrium real exchange rates at current price levels. Perhaps the most famous example in theory is the Dornbusch (1976) model, in which a monetary expansion leads temporarily to a large nominal depreciation that both exceeds and precedes the subsequent price increase. During the adjustment implied by the Dornbusch model, we would see a depreciation and then a subsequent appreciation of the real exchange rate.

The view that nominal shocks produce temporary disequilibrium real exchange rates depends on the belief that nominal prices are at least somewhat sticky in terms of domestic currency (more on this below). Aside from direct testing of this proposition, however, there is also the question of whether such nominal sources of real exchange rate movements are important in practice. An implication of nominal stickiness models of real exchange rate fluctuations is that such fluctuations should be temporary; the Dornbusch model, for example, is often taken to imply that the real exchange rate should follow a first-order autoregressive process. Yet a number of studies have been unable to reject the hypothesis that in the floating rate period real exchange rates have followed a random walk. This result is often taken as evidence that whatever the possible role of nominal shocks, in practice real exchange rate movements must represent primarily more-or-less permanent real shocks.

While appealing, this argument is wrong. In fact, the failure to find clear evidence of autoregression of real rates in the floating rate period does not demonstrate that nominal shocks are unimportant as sources of real exchange rate fluctuations. Instead, it should be viewed as a demonstration of the difficulty of discovering evidence of structural characteristics of the economy using theory-free time series methods. Quite strong autoregression in economic terms might well produce a time series that cannot be rejected as a 
random walk without many years of data; and the evidence is beginning to show that this is precisely what has happened with data on the real exchange rate.

A full-fledged treatment of this issue has been produced recently by Huizinga (1987). It may be useful, however, to have a semiformal treatment that makes the point to those (like myself) who are less than fully versed in the time series methods. (This exposition closely follows Frankel 1989.)

Consider, then, a situation in which the real exchange rate, measured as a deviation from its long-run equilibrium level, follows a process

$$
x_{t}=b x_{t-1}+e_{t}, \quad 0<b<1,
$$

where $e$ is an i.i.d. random variable with variance $s^{2}$. We may pose the "random walk" question as follows: how much data would we need to reject the hypothesis $b=1$ ?

A crude approach to this would be to simply estimate $b$ using ordinary least squares, and apply a $t$-test. It is by now familiar that this is not quite right, since under the null hypothesis that $b=0$ the assumption of boundedness for the right-hand-side variable is not valid. Even though this is not the right test, however, it is illuminating (at least to me) to see what we can expect by way of standard errors on $b$ when the true value is something less than one.

In a regression with only one independent variable, the true variance of the estimate of $b$ is

$$
\operatorname{var}(b)=s^{2} /[N \operatorname{var}(x)],
$$

where $N$ is the number of observations. In turn, the variance of $x$ generated by the process described is $s^{2} /\left(1-b^{2}\right)$. Thus it turns out that the variance of the estimate is independent of the volatility of the shocks generating exchange rate fluctuations; it is simply equal to

$$
\left(1-b^{2}\right) / N
$$

Now consider what a fairly high degree of price stickiness might imply. Suppose that we are working with annual data and that $b=0.8$ - that is, the "half-life" of a nominal shock is five years. This is not an unreasonable number if one tries substituting typical estimates of the slope of the Phillips curve into an IS-LM model. Then the variance of the estimate of $b$ will be $0.36 / N$.

In order to put the true $b$ two standard deviations away from one, the variance of the estimate will need to be reduced to $(0.1)^{2}=0.01$. This will require thirty-six years of data! Thus it should be no surprise that the floating rate period has not yielded enough evidence to reject the hypothesis of no mean reversion. 
Nor are very long time series necessarily the answer (although Jeffrey Frankel has found that with a very long time series on the real dollar-pound rate, strong mean reversion can in fact be confirmed; see Frankel 1989). In long series, any drift in the real exchange rate over time will be correlated with the lagged rate, and a regression of the form of equation (1) will end up largely telling us this; in effect, by omitting variables representing structural change, one will end up biasing the results in such a way as to miss the mean reversion.

It is somewhat ironic that, given the way the failure to reject a random walk has been used in doctrinal debate, a random walk will be harder to reject the stickier are prices, and hence the more slowly the real exchange rate reverts to its long-run equilibrium. In a way, therefore, it is arguable that the high degree of persistence in real exchange rates found since 1973 is in fact evidence that fairly inflexible prices are the rule, and that therefore nominal shocks in fact have very large effects on real exchange rates.

This brings us, however, to the question of price behavior. Sometimes debates over exchange rate theory and policy are seen as simply another round in the eternal struggle between equilibrium and sticky price theories of macroeconomics. This is not entirely right; some of the crucial issues are not contingent solely on one's view about how prices behave. However, the question of whether nominal rate changes help facilitate real exchange rate changes is crucial to the subject of this paper and needs some discussion.

\subsubsection{Nominal and Real Exchange Rates}

Most economists would now agree that in the long run the real exchange rate is a real phenomenon, not affected by nominal currency parities. How one gets to the long run, however, may depend very much on nominal parities. If one pegs the nominal exchange rate at a level that, given current price levels, does not produce the long-run real exchange rate, then that long-run rate must be established through some combination of inflation in the undervalued countries and deflation in the overvalued.

How costly is this process? Even if one believed in high flexibility of prices, one might prefer to adjust the exchange rate in order to preserve a greater degree of domestic price stability; this was essentially the position of Fricdman (1953) in his classic defense of floating rates. However, the willingness of governments to defend nominal parities depends critically on their view about how much price rigidity there is in domestic currency. If prices were perfectly flexible, of course, wages and prices would move continuously and instantly to clear markets. Even if prices were not totally flexible, however, one could imagine a world in which residents of each country regarded themselves as part of a world economy, where national boundaries made little difference, and where workers and firms therefore tried to set prices and wages in a way that indexed them against exchange rate changes (as actually happens in "dollar- 
ized" economies like that of Israel a few years back). In such a world, exchange rates would have little real significance, since a nominal exchange rate change would simply have the effect of producing some combination of inflation in the depreciating country and deflation in the appreciating country. The neutrality of nominal exchange rates is a key theme of "global monetarists" such as McKinnon (1984), McKinnon and Ohno (1986), and Mundell (1987), sometimes expressed in the slogan that the exchange rate is the relative price of two moneys, not the relative price of two goods or two kinds of labor.

In fact, however, the experience of floating rates in the $1980 \mathrm{~s}$ - a period of relatively low inflation differentials among the major industrial countries - has given very clear evidence in favor of the view that prices are substantially rigid in domestic currency. Consider figures 4.1 and 4.2 , which show the U.S. nominal exchange rate (actually an average index against other OECD countries) versus an index of U.S. relative unit labor costs (using the same weights) and an index of the price of U.S. exports compared with the export prices of the rest of the OECD. It turns out that the nominal exchange rate has very nearly been the relative price of two kinds of labor, and of two goods as well.

Why is this true? Without taking a long detour into the new microfoundations of Keynesian economics, we may state the basic point briefly. Whether because of menu costs or bounded rationality, firms do not constantly change their prices and wage offers in response to changes in demand, nor do they index their prices optimally. Instead, they fix prices in nominal terms for fairly

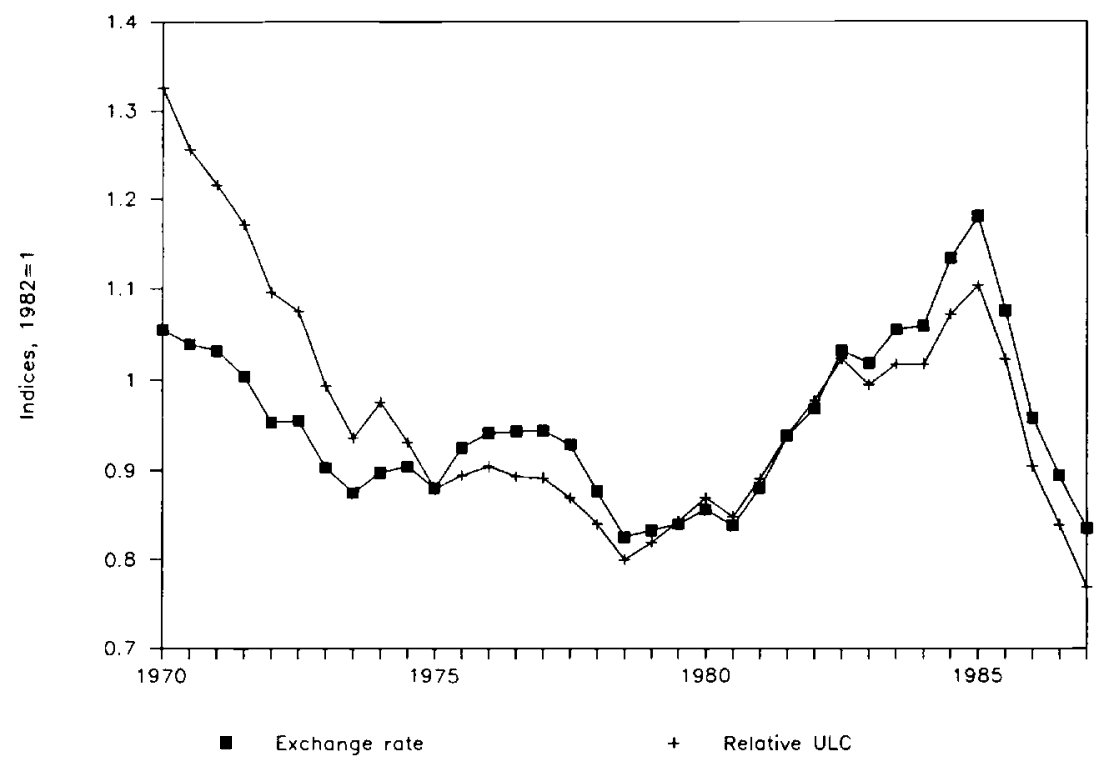

Fig. 4.1 Nominal vs. real exchange rate 


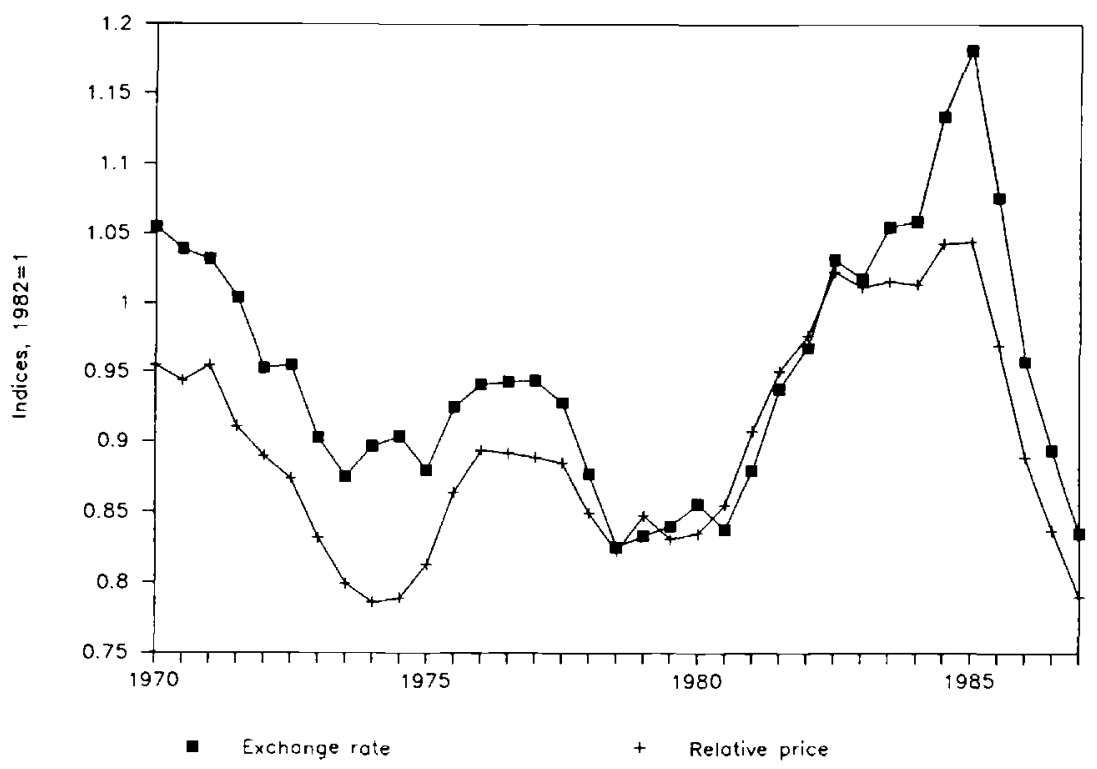

Fig. 4.2 Nominal vs. real exchange rate

long periods - and the overlapping pricing decisions of thousands of pricesetters create substantial inertia in the overall level of wages and prices.

The important addendum for international economics is that when prices are set in nominal terms, they are set in terms of domestic currency. In principle, this needn't happen. Prices in the Federal Republic of Germany could be set in dollars, or prices in Italy in ecu; the medium of exchange and the unit of account functions of money can be, and sometimes are, separated. In advanced countries, however, prices are sufficiently predictable that there is no need to turn to a foreign currency for a usable standard, unlike the situation in hyperinflation countries. And the fact is that domestic currency has a much more predictable purchasing power for residents of every advanced country than any foreign currency.

The only major objection to this evidence that makes any sense is the argument that the causation is actually running the other way-that what really happens is that real exchange rates are moving around for real reasons, and that the attempt of monetary authorities to stabilize domestic price levels creates the correlation between real and nominal rates. This view is often buttressed by an appeal to the apparent random-walk character of real exchange rates, which is taken as evidence that real rather than nominal shocks dominate exchange rate movements.

We have seen, however, that the evidence against mean reversion in real exchange rates is not well founded and may indeed be used as evidence of more, not less, price rigidity. There is also a question of plausibility. What were the real shocks that raised the equilibrium relative price of U.S. labor by 
15 percent from the first half of 1984 to the first half of 1985 , then drove it down by 20 percent over the following year?

There is also a further piece of evidence of the importance of nominal exchange rates. This is the way that changes in the exchange regime are strikingly reflected in changes in the behavior of real exchange rates. Suppose that one believed that real exchange rates were a real phenomenon, not affected by nominal rates. Then there would be no particular reason why a change in the exchange rate regime should alter the behavior of real exchange rates. In particular, one would expect real exchange rates to be no more variable under floating rates than under fixed.

Figure 4.3, which is borrowed from Rudiger Dornbusch and Alberto Giovannini, shows monthly changes in the real exchange rate (using wholesale prices as deflators) between the U.S. and Germany from 1960 to 1986 . That is, the first half of this figure shows the experience under fixed rates, the second half under floating rates. The variance of monthly changes in this real exchange rate was fifteen times as large in the second half of the sample as in the first.

In sum, then, there is at this point overwhelming evidence that nominal exchange rate changes do in the short run produce real exchange rate changes, and that the effects on the real exchange rate are quite persistent. The implication of this for the discussion of exchange rate policy is clear. First, if policymakers know where the equilibrium real exchange rate is headed, they can greatly facilitate adjustment by allowing or inducing nominal rates to move in that direction. Second, getting nominal rates wrong can be very costly because it may take a long time for the equilibrium real rates to get themselves established.

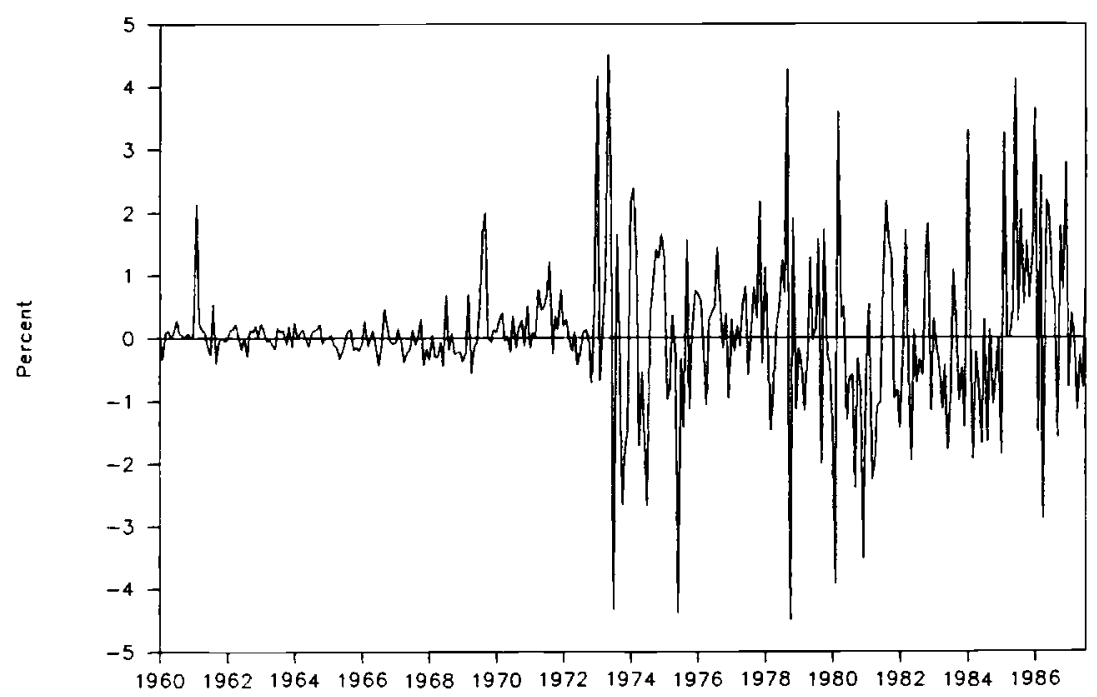

Fig. 4.3 Monthly real exchange rate changes 


\subsection{Long-run Trends in Equilibrium Real Exchange Rates}

Even though the evidence is now pretty clear that there is a strong element of mean reversion in real exchange rate behavior, long-run secular trends in equilibrium real rates still pose crucial problems for exchange rate stabilization. These problems are of two kinds. First, even a functioning system can be ripped apart if the secular trends run too quickly. Suppose, for example, that we could correctly estimate the sustainable dollar-yen rate at the present instant to be 130 , and that we are prepared to adjust the central parity in line with relative inflation. We will still find ourselves in trouble if there is a secular appreciation of the equilibrium real yen that raises the equilibrium yen, even after correcting for differential inflation, to ninety within five years. Arguably it was the secular decline in the equilibrium real dollar that really broke up Bretton Woods: the overvaluation of the dollar in 1971 owed little to a faster U.S. inflation rate since 1960 , and much to a decline in the real dollar compatible with international equilibrium.

Even more important than the question of drift in the future equilibrium rate is the problem of getting the rates right to start with. By any historical standard, the real yen looks extremely high right now. Yet Japan continues to run huge current account surpluses. What most econometric evidence suggests is that the explanation lies in a rapid secular upward trend in the equilibrium real yen. If correct, this interpretation tells us that the pace of secular change has been rapid enough to make the usual indicators of competitiveness useless over only an eight-year period.

It is important, then, to get at the determinants of long-run trends in equilibrium real exchange rates and to have some idea of their likely future path.

Broadly speaking, there are two major theories of secular trends in real exchange rates. First is the theory associated with Balassa (1964), which attributes such trends to differential productivity growth in tradable and nontradable sectors. Second is the alternative, more Keynesian approach associated with Johnson (1958) and Houthakker and Magee (1969), which puts the stress on growth rates and income elasticities. We consider each in turn.

\subsubsection{Tradables versus Nontradables}

Suppose that Japanese and American workers are equally productive in the manufacturing sector, but that the Japanese workers are only half as productive in the service sector. Since manufactured goods are generally traded and services generally nontraded, we would expect, other things being equal, to see rough equality between Japanese and U.S. wage rates, that is, to see relative wages determined by relative productivity in the traded goods sector. This will mean that services will be twice as expensive in Japan, and that a purchasing power parity (PPP) calculation that includes services will show a 
apparently overvalued yen. More to the point, if Japanese productivity growth continues to be concentrated in manufacturing to a greater extent than is the case for the United States, there will be a secular drift in the equilibrium real exchange rate if services are included in the deflators.

This is the essence of the differential productivity argument for trends in equilibrium real exchange rates. It was introduced by Kravis and Balassa both to explain trends in real exchange rates and to explain absolute differences in the cost of living across countries at a point in time. Marston (1987) has shown that interpretation of movements in the real exchange rate between the United States and Japan in the 1973-83 period must be heavily qualified by this Kravis-Balassa effect because Japanese productivity growth was so heavily concentrated in traded goods industries.

While the tradable-nontradable approach to trends in equilibrium real exchange rates identifies an important reason for secular trends, it is not a complete story. The reason is that changes in the relative price of tradables and nontradables would be the only source of real exchange rate changes only if PPP held over time for traded goods. As we have seen, however, in figure 4.2, there are large short-run swings in the relative prices even of exportables. Admittedly, it is possible to conceive of models in which large deviations from PPP for traded goods occur in the short run yet the law of one price for tradables holds in the long run; indeed, we will describe such a model below. Yet this need not be the case if countries in fact produce different mixes of goods. In practice there are several cases in which PPP for traded goods seems to be clearly violated in the long run. The United States has appeared to need significantly lower relative export prices in the late 1970s and 1980s in order to balance its trade than it needed in the late 1960s. Japan, on the other side, has a very strong currency by historical standards even when traded goods prices rather than more aggregated indices are used as the basis for the calculation, yet it continues to run large current surpluses.

To think about the role of shifts in traded goods PPP, it is necessary to shift to an alternative approach, one that emphasizes the imperfect substitution among exportables from different industrial countries.

\subsubsection{Income Elasticities and Secular Trends}

Although much theoretical literature in international economics is set in a general equilibrium framework with fairly complex production structures and many relative prices, the workhorse of practical trade balance analysis is still, as it was a generation ago, the partial equilibrium analysis of trade flows that are assumed to depend on real income and a single relative price. This framework can be defended as a pretty close approximation to a more carefully specified framework in which expenditure as well as income enters into import demand; in any case, since this framework is still the way most practical analysis is done, it will be used as the starting point here without much apology. 
Consider, then, a two-country world in which we define $y, y^{*}$ as domestic and foreign real output, $p, p^{*}$ as the prices in local currency of these outputs, and $e$ as the price of foreign currency in terms of domestic. Define $r=e p^{* / p}$ as the real exchange rate, which is in this case the price of foreign relative to domestic goods. Then the standard trade balance model may be written as follows. Export volume depends on foreign output and the relative price of domestic goods:

$$
x=x\left(y^{*}, r\right) .
$$

Import volume depends on domestic income and the relative price of imports:

$$
m=m(y, r)
$$

The trade balance (in domestic currency) may be written

$$
B=p x-e p^{*} m=p(x-r m),
$$

so that the trade balance in terms of domestic output is simply

$$
b=x-r m \text {. }
$$

Now it was pointed out in the 1950s by Johnson (1958) that if the framework given by equations (2)-(5) is a reasonable description of trade balance determination, then economic growth is likely to require secular changes in real exchange rates. To see why, define the following. Let $z_{x}=$ income elasticity of demand for exports; $z_{m}=$ income elasticity of demand for imports; $e_{x}=$ price elasticity of demand for exports; $e_{m}=$ price elasticity of demand for imports; $y^{\prime}=$ rate of growth of domestic output, that is, $(d y / d t) / y ; y^{*^{\prime}}=$ rate of growth of foreign output; and $r^{\prime}=$ rate of real depreciation.

Now differentiate equation (4). We have

$$
d b / d t=x\left(z_{x} y^{* \prime}+e_{x}^{r^{\prime}}\right)-r m\left[z_{m} y^{\prime}+\left(1-e_{m}\right) r^{\prime}\right]
$$

Suppose that initially $b=0$, so that $x=r m$. Then in order to keep a zero trade balance, we must have

$$
z^{x} y^{* \prime}-z^{m} y^{\prime}+\left(e^{x}+e^{m}-1\right) r^{\prime}=0
$$

This implies a trend in the real exchange rate of

$$
r^{\prime}=\left(z_{m} y^{\prime}-z_{x} y^{*^{\prime}}\right) /\left(e_{x}+e_{m}-1\right)
$$

Equation (8) immediately identifies two reasons why there may be a trend in the equilibrium exchange rate: either countries may face different elasticities of import and export demand, or they may have different long term rates of growth. More generally, there will be a trend in the real exchange rate unless 


$$
z_{x} / z_{m}=y^{\prime} / y^{*^{\prime}},
$$

which we would a priori imagine to be unlikely.

Econometric estimates of trade equations along the lines of equations (2) and (3) generally find two things. First, price elasticities are fairly small. While a great deal of effort has gone into trying to push up price elasticity estimates, on the presumption that they are understated due to mismeasurement or long lags, standard estimates remain in the range $1-2$. This implies that goods produced in different countries are quite imperfect substitutes, so that differences in growth rates or in income elasticities can produce large secular trends in relative prices. Second, there is indeed a wide spread of estimated income elasticities. Tables 4.1 and 4.4 present two sets of estimates of income elasticities: the Houthakker-Magee estimates from 1969 and a more recent set from Krugman (1988a). What is clear is that there is a very wide range of results.

So we might expect to find that strong trends in equilibrium real exchange rates even when only traded goods are considered will be the norm rather than the exception. However, inspection of very long time series shows that this is less true than one might expect. For example, Frankel (1989) has computed the real (CPI) exchange rate between Britain and the United States since 1870. Instead of a gradual secular drift, the series gives the definite impression of a persistent mean reversion, which leaves the real exchange rate little changed over more than a century.

Why does long-run PPP work as well as it does? The immediate answer is a systematic association between relative growth rates and apparent income elasticities, which I have called the "45-degree rule." The deeper explanation of the 45 -degree rule is a more debatable issue.

\subsubsection{The 45-Degree Rule}

In 1969 Houthakker and Magee published a paper that remains a benchmark for comparative estimation of trade equations across a large number of countries. Their main conclusion was that there were large differences among countries in their relative income elasticities-specifically, that Japan faced the highly favorable combination of a high-income elasticity of demand for its exports and a low-income elasticity of import demand, while the United States and the United Kingdom faced the reverse. While Houthakker and Magee did of course notice that Japan was the fastest growing country in their sample, while the United States and the United Kingdom were the slowest, they did not explicitly consider the possibility that the differences in underlying growth rates were somehow systematically related to the differences in estimated income elasticities. Yet it is difficult to escape this conclusion. Table 4.1 presents the Houthakker-Magee income elasticity results for industrial countries, together with the growth rates of those countries over the period 
Table 4.1 Income Elasticities and Growth Rates in the 1950s and $1960 \mathrm{~s}$

\begin{tabular}{lllll}
\hline & \multicolumn{2}{c}{ Income Elasticity } & & \\
\cline { 2 - 3 } Country & Imports & Exports & Ratio & Growth rate, 1955-65 \\
\hline United Kingdom & 1.66 & 0.86 & 0.52 & 2.82 \\
United States & 1.51 & 0.99 & 0.66 & 3.46 \\
Belgium & 1.94 & 1.83 & 0.94 & 3.77 \\
Sweden & 1.42 & 1.76 & 1.24 & 4.18 \\
Norway & 1.40 & 1.59 & 1.36 & 4.41 \\
Switzerland & 1.81 & 1.47 & 0.81 & 4.66 \\
Canada & 1.20 & 1.41 & 1.18 & 4.66 \\
Netherlands & 1.89 & 1.88 & 0.99 & 4.67 \\
Denmark & 1.31 & 1.69 & 1.29 & 4.74 \\
Italy & 2.19 & 2.95 & 1.35 & 5.40 \\
France & 1.66 & 1.53 & 0.92 & 5.62 \\
Germany & 1.80 & 2.08 & 1.56 & 6.21 \\
Japan & 1.23 & 3.55 & 2.89 & 9.40 \\
\hline
\end{tabular}

Source: Income elasticities from Houthakker and Magee (1969); growth rates from International Financial Statistics.

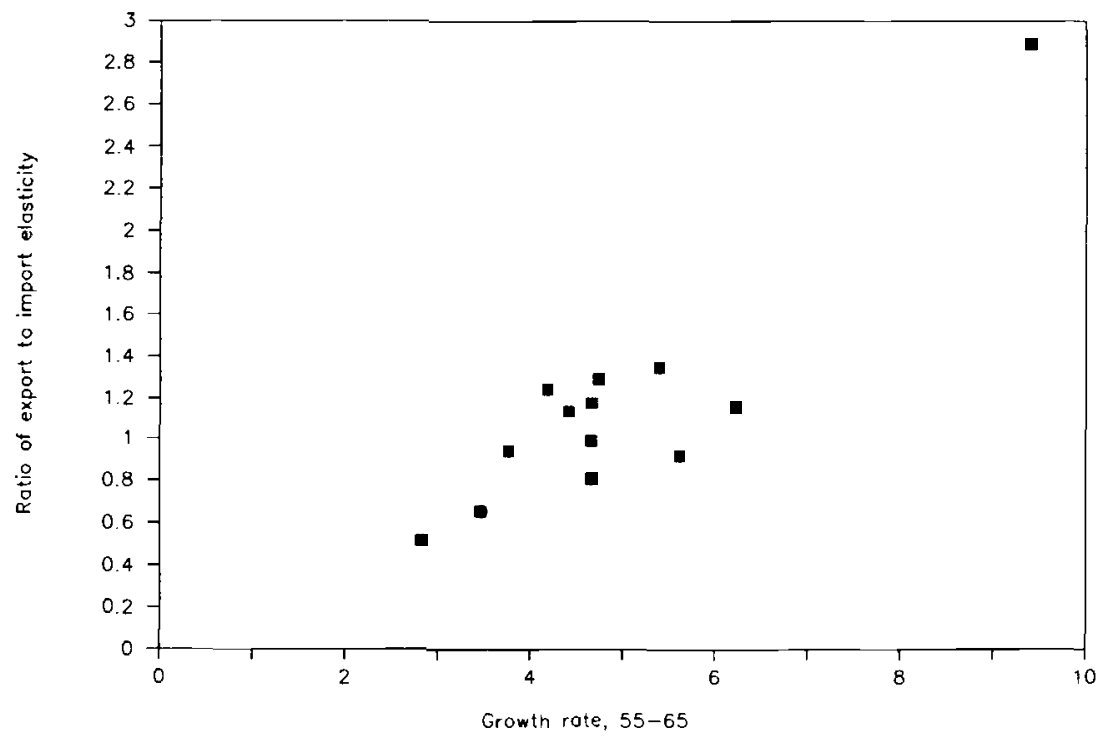

Fig. 4.4 Growth vs. elasticity ration, 1955-1965

1955-65. The relationship is striking; it becomes even more so when the ratio $z_{x} / z_{m}$ is graphed against $y^{\prime}$, a plot shown in figure 4.4 .

Basically, what the Houthakker-Magee results show is that equation (9) holds - that is, the ratio of income elasticities over their estimation period was such as to allow countries to have very different growth rates without strong 
trends in equilibrium real exchange rates. This may be confirmed more formally, by regressing the natural logarithm of the Houthakker-Magee elasticity ratio on the national growth rates:

$$
\begin{gathered}
\ln \left(z_{x} / z_{m}\right)=-1.81+1.210 \ln \left(y^{\prime}\right), \\
(0.0208) \\
R^{2}=0.754, \mathrm{SEE}=0.211 .
\end{gathered}
$$

In this regression we see that on average, if country A grew twice as rapidly as country B over the period 1955-65, then country A turned out to have an estimated ratio of export to import elasticities that was twice that of country B.

The result of this systematic relationship between growth rates and income elasticities was to make relative PPP hold much better than one would have expected if one assumed that income elasticities were identical, or distributed randomly. One might have expected Japan to need to have rapidly falling relative export prices in order to accommodate its extremely rapid economic growth - but the combination of high export elasticity and low import elasticity took care of that. One might have expected the United Kingdom to receive compensation for its low growth rate by a secular appreciation of its real exchange rate-but the combination of low export elasticity and high import elasticity deprived it of that benefit.

A similar though less clear-cut relationship between growth rates and income elasticities is apparent in more recent data. (The reason the result is less clear is probably that the spread of growth rates has narrowed.) Tables 4.2 and 4.3 report the results of a set of standard export and import equations estimated for industrial countries on annual data for the period 1971-86. The dependent variables are $X=$ manufactures exports in 1982 prices and $M=$ manufactures imports in 1982 prices. The explanatory variables are $Y=$ GNP in constant prices; $Y^{*}=$ foreign GNP in constant prices, calculated as a geometric average of GNP in fourteen industrial countries, weighted by their 1978 shares of the exporting country's exports; RXP = OECD index of relative export prices of manufactures; and RMP = relative price of manufactures imports, calculated as ratio of manufactures import unit value to GNP deflator.

All data are from OECD Economic Outlook. All equations were estimated in log-linear form; where severe serial correlation was evident, a correction was made.

By and large, these estimates look fairly decent; taken one at a time, they might suggest the need for more careful cleaning of data, addition of some extra variables, etc., but they would not discourage a researcher from using the income and price elasticity framework. The major exception is the United Kingdom, whose import equation refuses to make sense; I have not been able to resolve this puzzle, and will drop the United Kingdom from subsequent discussion. 
Table 4.2

Estimates of Export Equations, 1971-1986 ${ }^{a}$

\begin{tabular}{|c|c|c|c|c|c|c|c|}
\hline \multirow[b]{2}{*}{ Country } & \multicolumn{2}{|c|}{ Coefficients on } & \multirow[b]{2}{*}{$\mathrm{RXP}(-1)$} & \multirow[b]{2}{*}{ SEE } & \multirow[b]{2}{*}{$R^{2}$} & \multirow[b]{2}{*}{ D-W } & \multirow[b]{2}{*}{$\rho$} \\
\hline & $Y^{*}$ & RXP & & & & & \\
\hline Austria & $\begin{array}{c}3.05 \\
(0.10)\end{array}$ & $\begin{array}{r}-0.56 \\
(0.42)\end{array}$ & $\begin{array}{c}-0.04 \\
(0.42)\end{array}$ & 0.03 & 0.992 & 2.11 & - \\
\hline Belgium & $\begin{array}{c}1.24 \\
(0.13)\end{array}$ & $\begin{array}{c}0.39 \\
(0.16)\end{array}$ & $\begin{array}{c}-0.58 \\
(0.14)\end{array}$ & 0.02 & 0.971 & 2.18 & - \\
\hline Canada & $\begin{array}{c}2.87 \\
(0.09)\end{array}$ & $\begin{array}{c}0.62 \\
(0.20)\end{array}$ & $\begin{array}{c}0.18 \\
(0.18)\end{array}$ & 0.02 & 0.996 & 1.96 & - \\
\hline Germany & $\begin{array}{c}2.15 \\
(0.09)\end{array}$ & $\begin{array}{c}-0.32 \\
(0.23)\end{array}$ & $\begin{array}{c}-0.23 \\
(0.21)\end{array}$ & 0.03 & 0.987 & 2.11 & 一 \\
\hline United Kingdom & $\begin{array}{c}1.30 \\
(0.08)\end{array}$ & $\begin{array}{c}0.00 \\
(0.14)\end{array}$ & $\begin{array}{r}-0.54 \\
(0.13)\end{array}$ & 0.03 & 0.963 & 2.01 & - \\
\hline Italy & $\begin{array}{c}2.41 \\
(0.11)\end{array}$ & $\begin{array}{c}0.08 \\
(0.19)\end{array}$ & $\begin{array}{c}-0.31 \\
(0.20)\end{array}$ & 0.04 & 0.982 & 1.61 & - \\
\hline Japan & $\begin{array}{c}1.65 \\
(0.80)\end{array}$ & $\begin{array}{c}-0.35 \\
(0.18)\end{array}$ & $\begin{array}{c}-0.53 \\
(0.21)\end{array}$ & 0.06 & 0.978 & 2.19 & 0.81 \\
\hline Netherlands & $\begin{array}{c}3.86 \\
(0.66)\end{array}$ & $\begin{array}{r}-0.56 \\
(0.22)\end{array}$ & $\begin{array}{r}-0.20 \\
(0.29)\end{array}$ & 0.03 & 0.980 & 1.46 & 0.94 \\
\hline United States & $\begin{array}{c}1.70 \\
(0.08)\end{array}$ & $\begin{array}{c}-0.44 \\
(0.16)\end{array}$ & $\begin{array}{r}-0.98 \\
(0.16)\end{array}$ & 0.04 & 0.976 & 2.10 & - \\
\hline
\end{tabular}

aAll equations estimated on annual data, 1971-86. Standard errors.

Table 4.3

Estimates of Import Equations, 1971-1986

\begin{tabular}{|c|c|c|c|c|c|c|c|}
\hline \multirow[b]{2}{*}{ Country } & \multicolumn{3}{|c|}{ Cuefficients on } & \multirow[b]{2}{*}{ SEE } & \multirow[b]{2}{*}{$R^{2}$} & \multirow[b]{2}{*}{ D-W } & \multirow[b]{2}{*}{$\rho$} \\
\hline & $\gamma$ & RMP & $\operatorname{RMP}(-1)$ & & & & \\
\hline Austria & $\begin{array}{c}2.94 \\
(0.99)\end{array}$ & $\begin{array}{r}-0.14 \\
(0.43)\end{array}$ & $\begin{array}{c}0.41 \\
(0.75)\end{array}$ & 0.04 & 0.979 & 1.74 & 0.41 \\
\hline Belgium & $\begin{array}{c}1.99 \\
(0.10)\end{array}$ & $\begin{array}{c}-0.39 \\
(0.16)\end{array}$ & $\begin{array}{c}0.14 \\
(0.15)\end{array}$ & 0.03 & 0.975 & 1.62 & - \\
\hline Canada & $\begin{array}{c}1.66 \\
(0.27)\end{array}$ & $\begin{array}{c}-0.79 \\
(0.51)\end{array}$ & $\begin{array}{r}-0.66 \\
(0.51)\end{array}$ & 0.07 & 0.916 & 1.66 & 0.40 \\
\hline Germany & $\begin{array}{c}2.83 \\
(0.26)\end{array}$ & $\begin{array}{c}-0.33 \\
(0.20)\end{array}$ & $\begin{array}{c}0.24 \\
(0.26)\end{array}$ & 0.03 & 0.988 & 1.24 & 0.54 \\
\hline United Kingdom & $\begin{array}{c}-0.20 \\
(0.09)\end{array}$ & $\begin{array}{c}1.03 \\
(0.05)\end{array}$ & $\begin{array}{c}-0.04 \\
(0.04)\end{array}$ & 0.01 & 0.999 & 1.95 & 0.95 \\
\hline Italy & $\begin{array}{c}3.65 \\
(0.37)\end{array}$ & $\begin{array}{c}-0.51 \\
(0.20)\end{array}$ & $\begin{array}{c}-0.17 \\
(0.14)\end{array}$ & 0.04 & 0.981 & 1.69 & - \\
\hline Japan & $\begin{array}{c}0.80 \\
(1.19)\end{array}$ & $\begin{array}{c}0.03 \\
(0.29)\end{array}$ & $\begin{array}{c}-0.45 \\
(0.38)\end{array}$ & 0.12 & 0.928 & 1.51 & - \\
\hline Netherlands & $\begin{array}{c}2.66 \\
(0.46)\end{array}$ & $\begin{array}{r}-0.11 \\
(0.14)\end{array}$ & $\begin{array}{c}-0.11 \\
(0.19)\end{array}$ & 0.02 & 0.987 & 2.13 & 0.79 \\
\hline United States & $\begin{array}{c}1.31 \\
(0.44)\end{array}$ & $\begin{array}{c}0.11 \\
(0.34)\end{array}$ & $\begin{array}{c}-1.04 \\
(0.36)\end{array}$ & 0.08 & 0.957 & 1.62 & - \\
\hline
\end{tabular}


What we may note, however, is that there is still, as in the Houthakker-Magee (1969) results, a systematic tendency for high-growth countries to face favorable income elasticities. Table 4.4 presents a summary of estimated income elasticities, their ratios, and growth rates (calculated by fitting trends to domestic and foreign GNP). When these results are plotted in figure 4.5, the result is less striking than for the Houthakker-Magee data in figure 4.4 - partly because the spread of growth rates is smaller-but the upwardsloping relationship is still apparent. On average the 45-degree rule continues to hold, although with much less confidence:

$$
\begin{aligned}
& \ln \left(z_{x} / z_{m}\right)=-0.00+1.029 \ln \left(y^{\prime} / y^{* \prime}\right), \\
&(0.609)
\end{aligned}
$$

Perhaps a more illuminating test is to look at the way in which estimates changed from the earlier period to the later period. In the 1950s and 1960s, as Houthakker and Magee (1969) noted, Japan was the country with highly favorable income elasticities, while the United States and the United Kingdom were the countries disfavored. In the 1970s and 1980s there was a general convergence of growth rates. European growth rates declined more than those of the United States, so that the United States grew almost as rapidly as its trading partners; Japan, though still fast growing, was not as far out of line as before. If there is some systematic reason why income elasticities seem to match relative growth rates, we should expect to find a decline in Japan's $z_{x} / z_{m}$ ratio and a rise in that of the United States. And indeed we do find this: according to the estimates made here, Japan's ratio of elasticities, while still high, is lower in my estimates than in the Houthakker-Magee results, while the United States actually is estimated to have a $z_{x} / z_{m}$ ratio greater than one.

Table 4.4

Income Elasticities and Growth Rates, 1970-1986

\begin{tabular}{llllllll}
\hline & \multicolumn{3}{c}{ Growth Rate of GNP } & & \multicolumn{3}{c}{ Income Elasticity } \\
\cline { 2 - 3 } Country & Domestic & Foreign & Ratio & & Exports & Imports & Ratio \\
\hline United States & 2.49 & 2.91 & 0.86 & 1.70 & 1.31 & 1.30 \\
Netherlands & 1.96 & 2.17 & 0.90 & 3.86 & 2.66 & 1.45 \\
Germany & 2.10 & 2.23 & 0.94 & 2.15 & 2.83 & 0.76 \\
Belgium & 2.15 & 2.19 & 0.98 & 1.24 & 1.99 & 0.62 \\
Italy & 2.56 & 2.37 & 1.08 & 2.41 & 3.65 & 0.66 \\
Austria & 2.63 & 2.08 & 1.26 & 3.06 & 2.60 & 1.18 \\
Canada & 3.59 & 2.55 & 1.41 & 2.87 & 1.66 & 1.73 \\
Japan & 4.15 & 2.37 & 1.75 & 1.65 & 0.80 & 2.06 \\
\hline
\end{tabular}

Source: Tables 4.2 and 4.3 . 


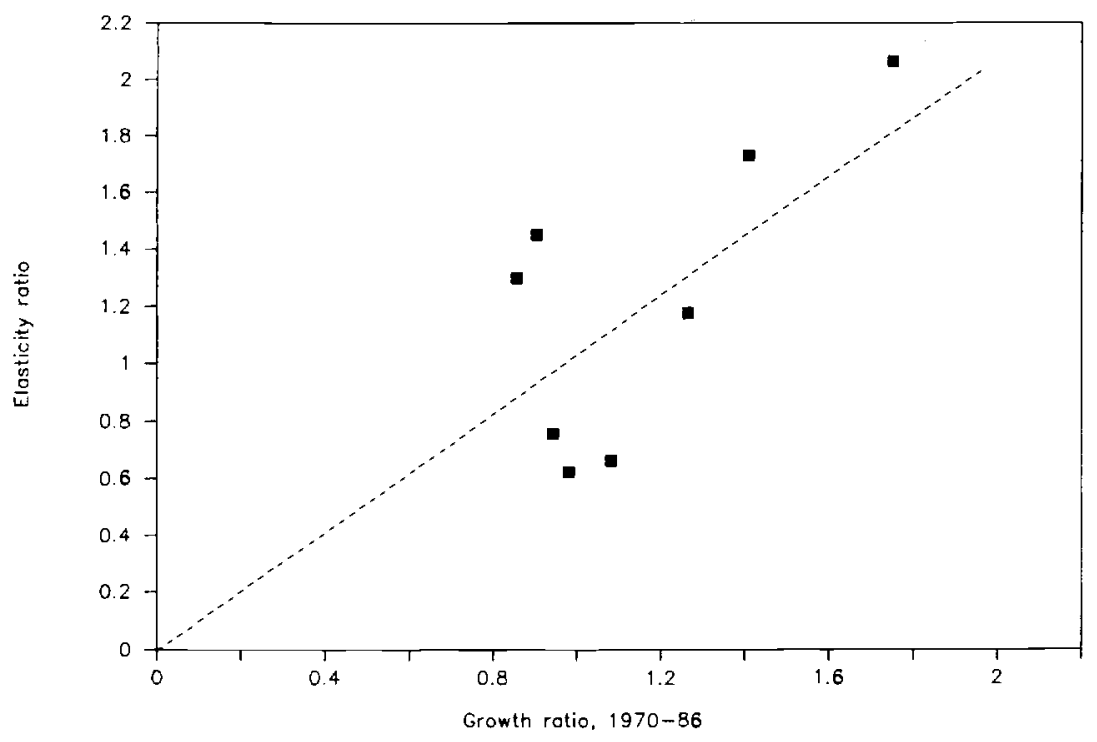

Fig. 4.5 Growth vs. elasticity ratio, 1970-1986

Clearly something is going on here. It seems unlikely that the systematic association of growth rates and income elasticities is a pure coincidence. So our next step is to turn to potential explanations.

\subsubsection{Why Does PPP Work So Well in the Long Run?}

There is a basic puzzle in relating short-run and long-run real exchange rate behavior. In the short run, PPP can be decisively rejected: both direct evidence on relative price behavior, as in Figure 4.2, and examination of econometric trade equations clearly demonstrate that goods produced in different countries are very imperfect substitutes. Yet in the long run, PPP works fairly well; this is reconciled with the low price elasticities of trade equations by the 45 -degree rule, which systematically relates income elasticities to relative growth rates.

The obvious candidate for an explanation of the 45-degree rule lies in supply-side effects. In Krugman (1988a) it is argued that conventional supply-side effects arising simply from outward shifts of supply curves, or even more complex effects arising from biased growth, cannot explain the kind of result that we see in the data. Instead, it is necessary to appeal to more exotic stories. Specifically, the 45 -degree rule can be explained if we argue that specialization among industrial countries is primarily due to increasing returns rather than comparative advantage; in this case goods currently produced by the industrial countries might be quite poor substitutes, but rough equality of (say) unit labor costs is enforced in the long run by the possibility that growing economies can widen the range of goods that they produce. 
The story runs as follows. Fast growing countries expand their share of world markets, not by reducing the relative prices of their goods, but by expanding the range of goods that they produce as their economies grow. What we measure as exports and imports are not really fixed sets of goods, but instead aggregates whose definitions change over time as more goods are added to the list. What we call "Japanese exports" is a meaningful aggregate facing a downward sloping demand curve at any point in time; but as the Japanese economy grows over time, the definition of that aggregate changes in such a way as to make the apparent demand curve shift outward. The result is to produce apparently favorable income elasticities that allow the country to expand its economy without the need for a secular real depreciation.

Krugman (1988a) offers as an illustrative example the case of trade between Dixit-Stiglitz-type economies that grow at different rates. The relative prices of representative goods produced in each country will remain unchanged, so all differences in export and import growth rates would be attributed by a conventional econometric analysis to income elasticity differences. It is straightforward to show that in this case econometric estimates will show precisely a 45-degree rule.

Admittedly, this suggested link between new trade theory, with its emphasis on noncomparative advantage specialization, and long-run real exchange rate behavior, is speculative. (I of course have a particular stake in its validity.) It does, however, have the virtue of providing a theoretical rationale for the deep-seated feeling of many international economists that PPP, however grossly violated it is in the short run, has substantially more validity in the very long run.

\subsection{Exchange Rates and the Adjustment Process}

We have seen that long-run secular trends in equilibrium exchange rates are probably less prevalent than one might have thought a priori, and that thus in the long run PPP may be a better guide than evidence of low price elasticities would have led one to conclude. However, much policy must still be made for the short and medium run, where an assurance that things will work out over a span of decades is not much help. Also, real shocks and secular trends still do shift equilibrium real exchange rates, so that the problem of adjusting to an appropriate real rate is still an issue.

Thus even given the long-run results suggested in the previous section, it remains important to ask the traditional question of the role of exchange rates in the adjustment process. Suppose that a country has a current account imbalance that it believes to be undesirable and unsustainable. What role can or should the exchange rate play in adjusting this imbalance?

This is actually a straightforward question, one which economists have understood well since the $1950 \mathrm{~s}$. However, recently the issue has become confused again. The reasons for this are puzzling; some economists have fallen into the trap of confusing accounting identities with behavioral descriptions, 
while others seem to have become so preoccupied with the subtleties of intertemporal models that they have lost touch with the basics. In any case, it seems necessary to restate the nature of the useful role that exchange rate adjustment can play in balance of payments adjustment.

\subsubsection{Expenditure-switching versus Expenditure-reducing}

The main source of confusion in the discussion of balance of payments adjustment has always been the fact that a country's balance of payments depends on at least two variables, and that a country with a balance of payments concern always has at least one other objective. The minimal situation is that of a country whose current account depends on both the level of domestic demand and the real exchange rate, and which cares both about the current account and the level of domestic employment.

Figure 4.6 reproduces the familiar diagrammatic exposition introduced by Swan (1963). On the axes are real domestic demand ("absorption") and the real exchange rate (measured here so that a rise represents a higher relative price for domestic goods). The line XX represents combinations of demand and the real exchange rate such that the current account is at some level regarded as desirable and/or sustainable; this is "external balance." The line II represents points where domestic resources are fully employed; this is "internal balance." The line XX is downward sloping because a rise in domestic demand, other things equal, will increase imports and siphon off exports; it must therefore be offset by a real depreciation to keep the current account unchanged. The line II is upward sloping because an increase in domestic demand will raise the demand for domestic output, unless a real appreciation shifts demand away from domestic goods. Each zone off the lines

Real exchange rate

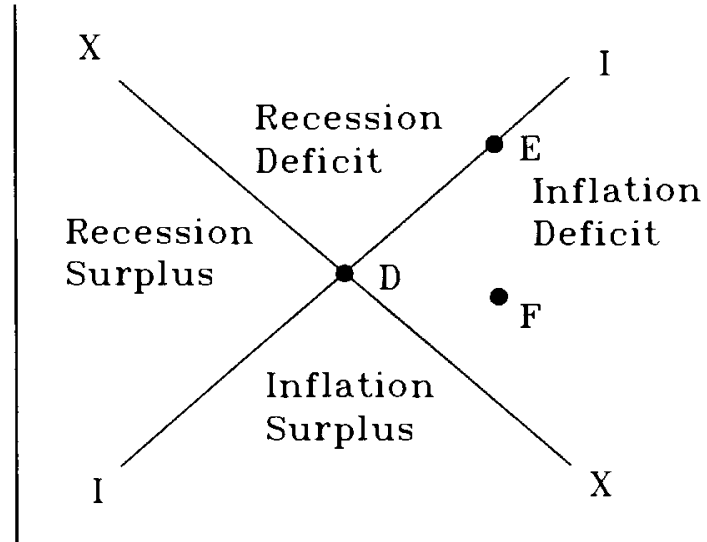

Real domestic demand

Fig. 4.6 
is characterized by a particular sort of disequilibrium. For example, points to the right of the equilibrium point $E$ are characterized by over-full employment and hence inflationary pressure, together with a balance of payments deficit.

The rough characterization of the United States with an overvalued dollar was that it was at a point like D: on the internal balance line, because unemployment was faiily close to the level regarded as compatible with price stability, but with an unsustainable current account deficit. To correct such a problem requires both a real depreciation and a reduction in domestic demand. Either alone leads to difficulties: a reduction in demand alone, that is, a move left from D, would improve the trade problem but lead to increased unemployment. A real depreciation without any fall in demand, that is, a move down from $\mathrm{D}$, would improve the trade problem but threaten inflation (this may be in the process of happening). Thus real depreciation and demand reduction are necessary complements.

This seems a straightforward and sensible enough analysis. Why has it come under attack? A number of writers, including most particularly McKinnon (1984), Mundell (1987), and the editorial staff of the Wall Street Journal, have argued that real depreciation is either unnecessary or impossible to achieve through nominal depreciation. Although this view is a regression from an understanding that one thought had been achieved and reopens an issue that ought to have been closed, it is influential and apparently persuasive enough to warrant some discussion.

\subsubsection{Is Real Exchange Rate Adjustment Necessary?}

The main focus of the attack on the need for real exchange rate adjustment is on the savings-investment identity, $X-M=S-I$. This says that the current account deficit is necessarily identical to the gap between savings and investment. The conclusion that many seem to have drawn is that this means that trade problems are purely financial problems, that an increase in savings will translate into a reduce external deficit without any need for real exchange rates to change. Indeed, McKinnon has repeatedly asserted that real exchange rate changes are necessary only in a world with limited capital mobility; once there is free movement of capital, changes in the savings-investment balance are reflected directly in trade, without the need to consider price elasticities.

It should be immediately apparent what is wrong with this argument; it neglects the question of what goods expenditure falls on. Figure 4.6 is entirely consistent with the savings-investment identity, but it adds the additional information that a fall in domestic demand will fall at least partly on domestic goods, leading to an excess supply that must be offset by a fall in these goods' relative price. Ultimately trade flows reflect real demands for real goods and services, and no amount of emphasis on the financial side should be allowed to gloss over that basic truth.

Now there is a more sophisticated argument about why real exchange rate changes might not be necessary, one that actually goes back to the KeynesOhlin debate over the transfer problem. Suppose that the United States reduces 
its real expenditure by 100 billion constant dollars. By the world budget identity, other countries must increase their expenditure correspondingly. In principle other countries could increase their demand for U.S. goods and services by enough to compensate for the reduced domestic demand, even at a constant real exchange rate. In this case no real depreciation would be necessary.

Is this likely? The question is precisely that which arises in the classic transfer problem: how does the marginal propensity of U.S. residents to spend on U.S. goods compare with that of foreign residents? In a perfectly integrated world inhabited by people with identical homothetic preferences, these marginal propensities would be the same. In the real world, which remains very imperfectly integrated, there is no reasonable doubt that U.S. residents spend a much higher fraction of any marginal change in spending on U.S. goods.

Tautologically, the answer may be regarded as the product of two terms: the share of imports in expenditure and the elasticity of imports with respect to expenditure.

First, we ask what share of U.S. expenditure falls on foreign goods. One might be inclined to answer with the share of imports in GNP, or in GNP plus the trade deficit (to take account of the fact that expenditure currently exceeds income): that is, about 11 percent. This is not a very large number given the alarms being raised about international competition in the United States, but it is in any case the wrong number; it is too large by a factor of perhaps two. On average, U.S. residents probably spend only 5 or 6 percent of their income on imports. The reason is that something like half of U.S. imports are intermediate goods. The spending on these goods is presumably related to U.S. output rather than expenditure; this makes an important difference, as we will see, and this needs to be kept separate.

Next, we poll the econometricians for an elasticity. Import demand is generally estimated to rise more than proportionally to whatever activity variable the econometrician puts in, for fairly obvious reasons: goods, which are traded more than services, respond more to cyclical fluctuations in spending, and capacity constraints cause some of an increase in demand to spill over into imports. However, the typical elasticity of imports with respect to spending or income is usually around 2 and rarely more than 3 .

Putting these together, we find that a generous estimate of the share of a marginal dollar spent on imports will still be less than 20 cents. Taking a round number, then, let us suppose that U.S. residents spend 80 percent of a marginal dollar on U.S. goods. What about foreign residents?

Here we note that the United States is less than a third of the world market economy. Thus even in normal times, when U.S. trade is roughly balanced, U.S. exports constitute only about 5 percent of the income of the rest of the world, and less of their final expenditure. Again a generous estimate might be that foreign residents will spend 10 cents of a marginal dollar on U.S. goods. 
Thus a minimal estimate is that U.S. residents spend eight times as high a share of a marginal increase in spending on U.S. goods than do foreigners. This disparity is no doubt smaller than it ever was-but in an important sense we are still closer to a world in which all of a spending shift falls on domestic goods than we are to one in which spending is fully internationalized.

Now return to our assumed case, in which U.S. residents reduce their expenditure by $\$ 100$ billion, while foreign residents correspondingly increase their expenditure by the same amount. The results are illustrated in table 4.5.

Case $\mathrm{A}$ in table 4.5 shows what happens, all else equal, if U.S. spending falls by $\$ 100$ billion and rest of world (RoW) spending rises by the same amount. The key point is that, as we have argued, U.S. residents have a much higher marginal propensity to spend on U.S. goods than RoW residents. When U.S. spending falls by $\$ 100$ billion, U.S. spending on imports falls by only $\$ 20$ billion, while domestic demand for U.S. goods falls by $\$ 80$ billion. The increase in RoW spending provides a new source of demand for U.S. exports, but not nearly enough: out of the $\$ 100$ billion rise in RoW spending, only $\$ 10$ billion falls on U.S. products. The result, then, is to produce a $\$ 70$ billion excess supply of U.S. goods and a $\$ 70$ billion excess demand for RoW goods.

How are we to make the redistribution of world expenditure effective? Somehow the world needs to be persuaded to switch $\$ 70$ billion of spending from RoW goods to U.S. goods. The only nonprotectionist way to do this is to make U.S. goods relatively cheaper. That is, we need real depreciation of the United States against the rest of the world.

The reason why this real depreciation is needed is precisely that world markets for goods and services are imperfectly integrated, so that residents of each country have a much higher propensity to spend on their own products than foreigners have to spend on that country's products. So the microeconomic fact of an imperfectly integrated world market has the macroeconomic implication that real exchange rate changes are an essential part of the balance of payments adjustment process.

Because of the imperfect integration of world markets for goods and services, then, current account adjustment does require real exchange rate adjustment. However, it is not necessary that this occur through a nominal depreciation of the dollar. Instead of dollar decline, we could achieve the same

Table 4.5 Reducing a Trade Imbalance

\begin{tabular}{lccc}
\hline Case & Total Spending & Spending on U.S. Products & Spending on RoW Products \\
\hline A: & & & \\
U.S. & -100 & -80 & -20 \\
RoW & +100 & +10 & +90 \\
B: & -100 & -80 & -20 \\
U.S. & +800 & +80 & +720 \\
RoW & & & \\
\hline
\end{tabular}


result through a combination of deflation in the United States and inflation abroad. The need for real exchange rate adjustment is only a case for nominal exchange rate flexibility if relative prices and wages are more easily altered through exchange rate changes than through differential price level movements. But it was shown earlier in this paper that substantial stickiness of prices and wages in domestic currency is in fact a major feature of the world economy. Because there is in fact inertia to nominal prices, it is easier to reduce the relative price of U.S. labor and output via a dollar depreciation than via U.S. deflation. Thus the case for real exchange rate changes in the adjustment process is also a case for nominal exchange rate changes to facilitate this adjustment.

\subsubsection{The Role of Growth in Surplus Countries}

In the numerical illustration in part A of table 4.5 , it is assumed that the fall in U.S. expenditure is matched by only an equal rise in RoW expenditure. Many in the United States have argued, however, that growth in surplus countries-which means a rise in RoW expenditure over and above the fall in U.S. expenditure, whether they realize it or not—should take the place of exchange rate adjustment. This is a point that is correct conceptually, but there just isn't much in it as a practical matter. I want to return to table 4.5 , part B, in order to see why.

Let us pose the following question: How much would foreign expenditure have to rise in order to allow the United States to cut expenditure by $\$ 100$ billion and convert all of that cut into a trade balance improvement, without the need for a real depreciation to induce a switch of expenditure to U.S. goods? The answer is shown in part B. Since the fall in U.S. expenditure reduces the demand for U.S. goods by $\$ 80$ billion, and we are assuming that only 10 percent of a marginal increase in RoW spending falls on U.S. goods, expenditure in the rest of the world must rise by $\$ 800$ billion. In this way the total spending on U.S. goods is left unchanged, with the decline in domestic demand offset by an equal increase in export demand.

Unfortunately, there is a side consequence: the total expenditure on RoW goods rises by $\$ 700$ billion- $\$ 720$ billion increase in domestic demand minus the $\$ 20$ billion fall in U.S. exports. Thus the alternative to U.S. depreciation offered here will work only if there is at least $\$ 700$ billion of usable excess capacity in the rest of the world. At current exchange rates, the GNP of market economies outside the United States is about $\$ 9$ trillion, so this means that to improve the U.S. trade position by $\$ 100$ billion using foreign growth as an alternative to real depreciation would require that we find room for an increase of almost 8 percent in RoW GNP. If we were to try to deal with the whole U.S. trade deficit in this way, the needed foreign growth would be more like 12 percent.

The problem should be immediately obvious - there isn't that much excess capacity in the surplus countries. Indeed, the IMF has estimated that none of 
industrial countries with current account surpluses have a usable excess capacity of more than 2 percent of GNP. This result may perhaps be challenged, but what matters is what the policymakers in the surplus countries believe; and the fact is that the authorities in the Federal Republic of Germany, in particular, regard themselves as having only small room for expansion at best. So the possibility of substituting growth in surplus countries for real exchange rate adjustment, while correct in principle, is only a minor issue in the current context.

\subsection{Problems of Assessment}

The expenditure-switching versus expenditure-reducing framework described in the previous section would offer a straightforward guide to exchange rate policy if there were neither structural change that shifted equilibrium exchange rates, nor lags in the effects of exchange rates on trade. Unfortunately, in reality both structural change and lags are key issues. Arguably, both have become even more serious issues in the 1980s than before. As a result, the assessment of equilibrium exchange rates remains a difficult and problematic exercise.

\subsubsection{Does the Dollar Need to Fall Further?}

As it happens, the current perplexity over the appropriate adjustment of the U.S. dollar provides a nice example of how uncertainty about lags and structural change interact to make determination of appropriate exchange rate policy very difficult. Suppose that we apply figure 4.6 to U.S. experience during the 1980s.

Suppose that there were neither structural change nor lags in the effects of the exchange rate. Then we would be able to draw internal and external balance schedules for the United States. In 1980, the United States was near most estimates of the NAIRU, and running a slight current surplus; thus the economy was at a point like D. By 1985, a massive expansion in domestic demand had been matched by a large dollar appreciation; economic recovery had raised employment back to a level approaching some estimates of the full employment level, so that the economy appeared to be at a point like E, on the internal balance line but with an external deficit.

Now as figure 4.6 shows, what has happened since 1985 is that the United States has experienced a substantial real depreciation that, depending on one's measure, has either brought the real exchange rate back to its 1980 level or brought it well below that level, without a corresponding fall in real demand relative to output. So the current situation ought to be represented by a point like F. In the absence of structural change or lags, we would expect to find a combination of persistence of the external deficit to at least some extent and inflationary pressure in the domestic economy. 
To some extent this has happened. The U.S. trade deficit has declined considerably in volume terms, and somewhat in dollar terms, while unemployment has fallen to levels that are somewhat below earlier estimates of the NAIRU. However, both the negative and positive effects of the real depreciation have been smaller than widely expected. To make the point, consider that constant dollar real expenditure in the United States currently exceeds constant-dollar output by approximately four percent. Suppose that in 1980 one had suddenly increased real expenditure in the United States by 4 percent. One would have expected this to have a substantial negative effect on the external balance, but not to be reflected almost one-for-one in the external deficit. One would also have expected a severe overheating of the domestic economy. The point is that the external deficit is larger-that the dollar's real depreciation has had less effect-than figure 4.6 alone would suggest.

Why should this be? Unfortunately there are two possible explanations. One is that the XX and II schedules have shifted in such a way as to reduce the equilibrium exchange rate; in effect, the declining dollar has been chasing a moving target. The other is that there are long lags in the effect of dollar decline, perhaps longer than in the past. The first explanation suggests that the dollar needs to decline substantially from its current level; the second, that what is needed is more patience.

The case for a decline in the equilibrium dollar has been advanced by a number of economists. It rests on the observation that at least four elements of the world environment have changed in ways that reduce the U.S. net export position at any given real exchange rate. These are: a) the continued relative decline of the U.S. advantage in technology over advanced rivals, which deprives the United States of the ability to sell goods at a premium; b) the debt crisis, which has reduced LDC imports from the world at large but disproportionately from the United States; c) slow growth in Europe, which has also depressed demand for U.S. exports; and d) the shift of the United States into net debtor status, which has eliminated the former U.S. surplus in investment income

Added to these factors is the possible role of "hysteresis" in trade: U.S. firms may have lost markets during the period of the strong dollar which it is not worth their while to recapture even with a return of the dollar to its original level.

By placing maximum weight on all of these factors, it is possible to make a case that the U.S. dollar needs as much as a 20 or even 30 percent depreciation below its 1980 level to be consistent with restoration of external balance.

On the other side, however, is the argument that such large shifts from PPP are rare historically, and that in time the United States should not have to depreciate its currency to a level that makes production costs radically lower than those in other advanced countries. This argument implies that what we 
are seeing is long lags in adjustment, and that given time there will be substantial further narrowing of the U.S. trade imbalance even at the current value of the dollar.

Ideally, econometric estimates of trade equations would identify lags. However, in practice this is difficult. Furthermore, there are some reasons to believe that the lags themselves may have changed. That is, lags in exchange rate responses may have become longer in recent years.

\subsubsection{Uncertainty and Lags in the Impact of Exchange Rates}

A striking feature of the period since 1985 has been the determination of non-U.S. firms in holding on to markets gained during the period 1980-85, despite a radical worsening of their relative cost position. U.S. firms also seem to have been reluctant to take advantage of the weaker dollar to attempt to regain lost markets. And multinational firms, wherever they are based, have been reluctant to reverse their location decisions from the strong dollar period.

One explanation of this lack of response to the weak dollar is that firms do not regard the current exchange rate as permanent, that they expect the dollar to return to levels of a few years ago. A broader explanation, however, which need not be specific to the dollar, is that uncertainty per se makes firms reluctant to respond to the exchange rate, and hence increases the lags in trade responses to the exchange rate. This point has been emphasized in recent theoretical work by Dixit (1988) and is emphasized in a practical context by Krugman (1988b).

The point may be made by considering a simple hypothetical example. Consider a hypothetical Japanese firm that has lost its cost advantage over U.S. rivals as the result of the strong yen. At the current exchange rate-say 120 yen to the dollar-it is losing money on its U.S. sales. This firm is not especially optimistic; it hopes that the yen may return to 140 , which would make it profitable again, but regards it as equally likely that the yen will rise to 100 , greatly increasing its losses. If that were the whole story, the firm would simply exit immediately. However, the firm has invested heavily in building its U.S. market position, and it knows that if it abandons that position now it will not be worth trying to regain it even if the yen does fall.

Table 4.6 shows some hypothetical numbers for this Japanese firm. We suppose that, at the current rate of 120 yen, it is losing money at an annual rate of $\$ 100$ million. If the yen goes back to 140 , it will be able to make $\$ 100$

\begin{tabular}{ccc}
\hline Value of Yen & Initial Year Loss & PDV of Later Years \\
\hline 100 & -100 & 0 \\
140 & -100 & 900 \\
\hline
\end{tabular}


million annually; if the yen rises to 100 , it will lose $\$ 300$ million per year if it still tries to hand on. Also, we suppose that the firm discounts future earnings at an annual rate of 10 percent.

The expected returns to this firm from sales in the U.S. market are clearly negative. However, the firm does not have to choose between leaving the U.S. market now and staying forever; its immediate choice is whether to exit now or wait a year, then choose again. And we can show that despite current losses the firm should hang in there for one more year.

Table 4.6 shows the returns to the firm if it chooses not to drop out and to wait instead for a year before making its decision. In the first year the firm loses $\$ 100$ million. In the second year it drops out if the yen goes to 100 , but stays in if it falls to 140. In this latter case, it will earn $\$ 100$ million per year thereafter, with a present value discounted to the first year of $\$ 900$ million. The overall expected present value to the firm of this wait-and-see strategy is therefore the average between what happens if the yen goes to 100 or to 140 : $\$ 350$ million.

By contrast, if the firm immediately drops out it makes nothing and loses nothing.

Clearly, in an expected value sense, the firm is better off holding on and hoping for better times even though it is losing money at the current exchange rate, and even though it regards an adverse movement in the rate as being as likely as a favorable movement. Of course, if the firm regarded a return to 140 as more likely than a rise to 100 , the case for remaining in the market in the face of losses would be even stronger.

Uncertainty, then, makes firms cautious about exiting from hard-won market positions. Similar examples will show that a U.S. firm will be hesitant about taking advantage of low costs to break into a market, and for that matter will make multinational firms hesitant about relocating production.

\subsection{Conclusions}

Experience and analysis have taught us a great deal about how a system of flexible exchange rates works. Unfortunately, we still do not know enough to give clear and simple advice in all circumstances to central bankers and finance ministers. In particular, the current situation is one in which an intelligent appreciation of what we know about equilibrium exchange rates leads to a definite "don't know" in response to questions about where to go from here.

What we do know are three things, in particular. First, nominal exchange rates matter. There is now overwhelming evidence for stickiness of prices in domestic currency, and the persistence of real exchange rate fluctuations is more likely evidence for slow price adjustment than it is for the prevalence of real shocks. Second, in the very long run, PPP works better than one might expect, possibly because of supply-side effects involving scale economies and product differentiation. Third, despite this, in the medium term the combination of strong distribution effects and fairly low price elasticities makes exchange rate changes an essential part of the adjustment process. 
The source of current perplexity is the difficulty of untangling different sources of change. Are the disappointing results of dollar depreciation due to structural changes or simply stretched-out lags? This is the key issue; at least by focusing on it we have a better chance of getting the right policy.

\section{References}

Balassa, Bela. 1964. The purchasing power parity doctrine: A reappraisal. Journal of Political Economy 72: 584-96.

Dixit, Avinash. 1988. Entry and exit decisions of a firm facing a fluctuating exchange rate. Mimeograph.

Dornbusch, Rudiger. 1976. Expectations and exchange rate dynamics. Journal of Political Economy.

Frankel, J. 1989. Quantifying international capital mobility. Paper presented at the NBER Conference on Saving, Maui, January 6-7.

Friedman, M. 1953. The case for flexible exchange rates. In Essays in Positive Economics. Chicago: University of Chicago Press.

Houthakker, H., and S. Magee. 1969. Income and price elasticities in world trade. Review of Economics and Statistics 51:111-25.

Huizinga, J. 1987. An empirical investigation of the long run behavior of real exchange rates. Paper presented at Carnegie-Rochester Conference.

Johnson, H. 1958. International trade and economic growth: Studies in pure theory. London: Allen and Unwin.

Krugman, P. 1988a. Differences in income elasticities and secular trends in real exchange rates. Paper presented at International Seminar on Macroeconomics, Tokyo, June.

1988b. Exchange Rate Instability. Cambridge, MA: MIT Press.

Marston, R. 1987. Real exchange rates and productivity growth in the United States and Japan. In S. Arndt, ed., Real-Financial Linkages in the Open Economy. Washington, DC: American Enterprise Institute.

McKinnon, R. 1984. An International Standard for Monetary Stabilization. Washington, DC: Institute for International Economics.

McKinnon, R., and K. Ohno. 1986. Getting the exchange rate right: Insular versus open economies. Paper presented at American Economic Association meeting, New Orleans, December.

Mundell, R. 1987. A new deal on exchange rates. Paper presented at a MITI symposium, Tokyo, January.

Swan, T. 1963. Longer-run problems of the balance of payments. In H. W. Arndt and W. M. Corden, eds., The Australian Economy: A Volume of Readings. Melbourne: Cheshire Press.

\section{Comment C. Fred Bergsten}

Paul Krugman has provided an outstanding analysis of how exchange rate changes contribute to the international adjustment process. His paper offers a

C. Fred Bergsten is the director of the Institute for International Economics. 
number of useful insights both for our intellectual understanding of the issue and for the continuing debate over exchange-rate policy.

In particular, Krugman underlines and reinforces the traditional view that currency changes can, and indeed must, play a central role in restoring and maintaining sustainable combinations of internal and external balance. As he notes, some observers have become disillusioned with the pace and magnitude of the decline in the external deficit of the United States (and the corresponding surpluses in Japan and Germany) despite the sizable fall of the dollar since early 1985. He cites a number of considerations to help explain this result and could have added several more.

First, most models show that the American current account deficit was headed toward annual levels of $\$ 300-\$ 400$ billion when the dollar was at its peak in early $1985 .^{1}$ Halting the deterioration at less than $\$ 150$ billion in 1987 , and subsequently cutting it by at least $\$ 20$ billion in nominal terms (and by much more in real terms), has thus been a considerable achievement.

Second, most analyses fail to take full account of the implications for achieving equilibrium of large initial imbalances. In the case of the United States, merchandise exports were only 60 percent as large as merchandise imports when the deficit peaked in 1987. Hence exports had to grow almost twice as fast as imports simply to avoid further increases in the deficit. The gap was even more dramatic in the case of the bilateral United States-Japan imbalance because Japanese exports were almost three times greater than American exports in 1987.

Third, many analyses fail to distinguish between real and nominal responses to currency changes and to the wide disparity between them. Cline remedies this problem and suggests that, for the United States, an improvement of $\$ 100$ billion in the nominal current account balance will require an adjustment of almost $\$ 200$ billion in real terms. ${ }^{2}$ Indeed, the U.S. deficit by the first quarter of 1989 had been cut by about 43 percent in real terms from its peak in the third quarter of 1986. The observed "sluggishness" of the response of the nominal deficit to a lower dollar thus masks much more substantial volume gains, which of course are of primary significance for the key variables in the real economy-growth, production, employment-and thus probably trade policy, though not for the financing of the imbalance.

Fourth, despite repeated international commitments to decisively reduce the budget deficit and despite the existence of the Gramm-Rudman-Hollings legislation, the United States failed at least through 1988 to complement dollar depreciation with adequate cutbacks in the growth of domestic demand. Domestic demand in fact continued to grow as rapidly, or more rapidly, than productive capacity. Supply constraints reportedly limited the expansion of exports in a number of sectors. ${ }^{3}$

Moreover, once the economy reached full employment and full capacity utilization by around the middle of 1988 (if not earlier), resources would have been available for additional reduction in the external imbalance only at the 
cost of a further acceleration of inflation. The Federal Reserve thus responded by tightening monetary policy, inter alia halting the depreciation of the dollar and in fact pushing it back up.

This fifth point-uncertainty on the part of the private sector concerning the future course of the exchange rate itself - is raised by Krugman but deserves even greater emphasis. Many American exporters, when asked why they have failed to expand productive capacity to satisfy both domestic and rising foreign demand, reply that they have no confidence that the exchange rate of the dollar would still be at a level permitting them to remain competitive internationally by the time the new capacity would come on stream.

Hysteresis thus has a critical time dimension. Krugman and others have argued that currencies probably need to overshoot to persuade firms to reenter export (and import-competing) markets. In addition, these firms may require assurances that exchange rates which permit them to compete will remain in place for some time. Indeed, there is presumably a tradeoff between the magnitude of the needed depreciation and its expected duration.

This suggests the need for systemic reform, to install and maintain an exchange rate regime that will offer such assurances. Here Krugman, despite calling for broad target zones in his widely praised Robbins lectures, ${ }^{4}$ concludes with surprising agnosticism that "we still do not know enough to give clear and simple advice in all circumstances to central bankers and finance ministers" and "what we know about equilibrium exchange rates leads to a definite 'don't know' in response to questions about where to go from here.'

Fortunately, the situation is not nearly so hopeless. Krugman has in fact slightly (but crucially) misspecified the problem: it is not whether economists can advise officials what to do "in all circumstances" but whether we can with some confidence offer them a system which promises to perform more effectively than either pure floating or the loose "reference ranges" installed with the Louvre Accord of February 1987.5

On this more modest criterion, there is growing evidence for the superiority of a system of target zones. Such a regime has been developed in detail, and simulated against recent history, by Williamson and Miller (1987). ${ }^{6}$ Both Branson and Frankel, in their presentations to this conference, indicate that the Williamson-Miller "blueprint" performs better than any of the proposed alternatives (or the status quo) ${ }^{7}$ As noted, Krugman has previously endorsed such an approach (and rightly stresses in his present paper the high costs of permitting wrong nominal rates to persist).

Such a system rests explicitly on the view that the exchange rate is an intermediate target, to be used to achieve and maintain current account positions that are agreed internationally to be sustainable in economic, financial, and policy (e.g., anti-protection) terms. Krugman's "most basic of these [exchange-rate] difficulties" should thus be restated: the hardest task, both intellectually and politically, will be to agree on targets for external and internal balance. It should then be an easier task to agree on currency zones 
that will help produce such outcomes, satisfying Krugman's dictum that policymakers can greatly facilitate adjustment by inducing nominal rates to move toward equilibrium once they know where equilibrium lies. Such a regime of course rejects the utility of purchasing power parity calculations for any practical purpose, for the reasons brilliantly developed in the paper, thus rendering even the yen zone (over which Krugman puzzles) susceptible to successful targeting.

Installing such zones in practice is a much trickier matter, however. The recent efforts of the Group of Seven to stabilize flexible exchange rates reveal that they are willing to try only "around current levels," 8 The authorities have been unable to find a technique to simultaneously alter levels and stabilize, as they could under fixed exchange rate regimes past (Bretton Woods) and present (European Monetary System), and there are admittedly great uncertainties as to whether such efforts could succeed within a context that continued to permit considerable rate flexibility. Hence any lasting monetary reform will probably have to be a two-step process, addressed initially to establishing equilibrium rates by completing the realignment begun in 1985 (perhaps through a "second Plaza agreement" ") and subsequently moving to a system of target zones to maintain equilibrium for the longer run.

\section{Notes}

1. Marris $(1987,86)$ foresaw a deficit of $\$ 320$ billion by 1990 with further increases thereafter. Simulations with the Federal Reserve's Helkie-Hooper model show a deficit of over $\$ 400$ billion by 1992 if the real exchange rate of the dollar had remained at its first-quarter 1985 level; see Cline $(1989,33)$.

2. See Cline (1989, ch. 6, especially $269-70)$.

3. A detailed proposal for linking the external and internal components of a U.S. adjustment strategy can be found in Bergsten (1988, especially ch. 4 and 5).

4. See Krugman (1988, especially 104-6).

5. See Funabashi (1988, especially ch. 8).

6. See Williamson and Miller (1987).

7. See also Currie and Wren-Lewis (1989, especially 199-200).

8. See Funabashi $(1988,183-86)$.

9. See Bergsten (1989).

\section{References}

Bergsten, C. Fred. 1988. America in the world economy: A strategy for the 1990s. Washington, DC: Institute for International Economics, November. 1989. U.S. priority objectives for the Paris Summit: A "Second Plaza Agreement" and the Uruguay Round. Statement before the Joint Economic Committee, U.S. Congress, July 6.

Cline, William R. 1989. United States external adjustment and the world economy. Washington, DC: Institute for International Economics, March.

Currie, David, and Simon Wren-Lewis. 1989. A comparison of alternative regimes for international macropolicy coordination. In Marcus Miller, Barry Eichengreen, and Richard Portes, eds., Blueprints for exchange rate management. London: Academic Press. 
Funabashi, Yoichi. 1988. Managing the dollar: From the Plaza to the Louvre. Washington, DC: Institute for International Economics, May.

Krugman, Paul. 1988. Exchange rate instability. Cambridge, MA: MIT Press.

Marris, Stephen. 1987. Deficits and the dollar: The world economy at risk. Washington, DC: Institute for International Economics, rev. August.

Williamson, John, and Marcus H. Miller. 1987. Targets and indicators: A blueprint for the international coordination of economic policy. Washington, DC: Institute for International Economics, September.

\section{Comment Michael Mussa}

It is a pleasure, once again, to comment on a stimulating paper by Paul Krugman. The last time I had such an opportunity was at a conference held in Grand Teton National Park in August 1985. On that occasion, I noted that the view of the Teton Range across Jackson Lake provided an appropriate setting in which to discuss the recent turbulent behavior of exchange rates. In light of recent official efforts to stabilize exchange rates, I rather suspect that Jacob Frenkel, now the Research Director and Economic Counsellor at the IMF, concluded that the tidelands of South Carolina would provide more suitable inspiration for today's discussion of exchange rate policy.

Just before lunch, Paul mentioned that he intended to take a walk and have a look at some of the local alligators. He didn't make clear whether he was seeking solace, or merely planning to get in a little practice for this afternoon's session. In fact, I agree with many of the points that Paul makes in his paper. In particular, in the last paper I wrote before joining the Council of Economic Advisers (see Mussa 1986), I attempted to document one of the key points that Paul discusses-real exchange rates have been much more volatile under the floating exchange rate regime that has prevailed since 1973 than under the Bretton Woods system of fixed exchange rates. As Paul emphasizes, this increased volatility of real exchange rates is closely associated with the increased volatility of nominal exchange rates and with the continued apparent sluggishness in the adjustment of national price levels. However, despite "the new micro-foundations of Keynesian economics," I am not as certain as Paul that we have a completely satisfactory understanding of the degree of price level inertia that appears to be associated with the large real exchange rate movements of the $1980 \mathrm{~s}$.

After summarizing the evidence that nominal exchange rate changes produce shorter-term but highly persistent changes in real exchange rates, Paul states two implications of this phenomenon for exchange rate policy. "First, if policymakers know where the equilibrium real exchange rate is headed, they

Michael Mussa is the William H. Abbott Professor of International Business at the Graduate School of Business, University of Chicago, and a research associate of the National Bureau of Economic Research. 
can greatly facilitate adjustment by allowing or inducing nominal rates to move in that direction. Second, getting nominal rates wrong can be very costly because it may take a long time for the equilibrium real rates to get themselves established." These statements suggest that Paul supports a quite activist role for exchange rate management as a tool of economic policy. However, the analysis in the remaining two-thirds of Paul's paper leads him to a far more cautious conclusion. "Unfortunately, we still do not know enough to give clear and simple advice in all circumstances to central bankers and finance ministers. In particular, the current situation is one in which an intelligent appreciation of what we know about equilibrium exchange rates leads to a definite 'don't know' in response to questions about where to go from here."

I share the conclusion that Paul reaches at the end of his paper, and I would like to suggest some further reasons for a cautious attitude toward the usefulness of exchange rate management.

Most importantly, in my judgement, much of the support for an activist policy of exchange rate management directed at reducing movements in real exchange rates is based on misconceptions concerning the causes and consequences of the major swing in the real foreign exchange value of the U.S. dollar during the 1980s. Certainly strong real appreciation of the U.S. dollar between the summer of 1980 and early 1985 created, or contributed to, a number of important economic problems, many of which have not been fully corrected by the subsequent depreciation of the dollar. These problems include the large and persistent U.S. trade deficit, the difficulties experienced by many tradable goods industries in the United States, and the protectionist sentiments that these difficulties have helped to engender. However, the existence of these important problems does not establish that most of the appreciation and subsequent depreciation of the U.S. dollar during the 1980 s was either avoidable or undesirable, given other events that were occurring in the world economy.

The tightening of U.S. monetary policy from late 1980 through the summer of 1982 was surely needed to bring down the U.S. inflation rate and restore confidence in the future conduct of U.S. monetary policy. Real appreciation of the U.S. dollar above what many economists believe to be its equilibrium path was an essentially inevitable consequence of this monetary policy. Further appreciation of the dollar in 1983 and 1984 probably reflected (among other things) the extremely strong recovery of the U.S. economy from the recession of 1981-82, together with continued success in keeping the inflation rate moderate. The appreciation of the dollar during this period surely helped to contain the inflationary pressures that probably would otherwise have accompanied this very rapid economic recovery. Also, the appreciation of the dollar and the associated growth of the U.S. trade deficit helped to spread some of the force of the rapid growth of domestic demand in the U.S. economy to other countries where growth of domestic demand remained very sluggish. Even with the moderating effects of dollar appreciation and a growing trade deficit, 
the Federal Reserve became sufficiently concerned with the threat of a resurgence of inflation, that monetary policy was tightened again between April and November of 1984. In view of the enormous costs of bringing down inflation in 1981-82, it is difficult to criticize the Federal Reserve for seeking to preserve its victory over inflation, even though the effect of monetary tightening in 1984 was almost surely to push the dollar further away from its longer-run equilibrium value.

The downward movement of the dollar from February 1985 through 1987 can be fairly characterized as a movement toward long-run equilibrium. Exchange rate management probably played a useful but subsidiary role in this exchange rate adjustment. The Plaza Agreement may have helped to accelerate dollar depreciation in the autumn of 1985 and in 1986. However, that process was already ongoing for six months before Plaza. The Louvre Accord and subsequent efforts at exchange rate stabilization may have contributed to greater stability of exchange rates since early 1987. However, in my judgement, the tightening of U.S. monetary policy because of concerns about renewed inflation and the evidence of improvement in the U.S. trade balance were probably far more important than exchange rate management in ending, and even partially reversing, the process of dollar depreciation.

In any event, the key development during the period of dollar depreciation since early 1985 is the absence of a "hard landing." Despite two years of precipitous decline in the foreign-exchange value of the dollar, and despite the worldwide stock market crash of October 1987, economic expansion continues in the United States and in most other industrial countries. Indeed, the improvement in the U.S. real trade balance since late 1986 (one of the desired effects of dollar depreciation) has clearly helped to keep the U.S. expansion going, despite a slower rate of growth of domestic demand in the United States. Recently, inflationary pressures may have picked up somewhat in the United States, but the U.S. inflation rate remains quite moderate in comparison with dire predictions of the consequences of dollar depreciation, and in spite of a relatively low unemployment rate. Of course, because of the recent tightening of monetary policy, or for other reasons, the U.S. economy could enter a recession in 1989 or 1990 . However, such a recession would not be unusual given the postwar history of U.S. business cycles. Thus, all things considered, the U.S. economy and the world economy do not appear to have suffered substantial damage from the correction in the foreign-exchange value of the dollar since early 1985 .

It is certainly possible that an active policy of exchange rate management or, more importantly, a better mix of monetary and fiscal policy could have avoided some of the appreciation of the dollar between 1980 and early 1985 . And, surely, cheering the dollar up at the end of its long period of appreciation was not a wise endeavor. However, the experience of the 1980s raises grave doubts about the feasibility and desirability of a policy that always seeks to drive the exchange rate toward some estimate of the value that would yield 
trade or current account balance. Sometimes it may be necessary or desirable to allow the exchange rate to move away from their longer-run equilibrium values, in order to accommodate powerful forces at work in the world economy, or in order to provide latitude for economic policy to pursue objectives more important than the rapid achievement of current account equilibrium.

This general reason for caution about policies' exchange rate management has considerable current relevance. Recognizing that we really don't know how much more, if at all, the dollar needs to depreciate, suppose, for the sake of argument, that we knew that the dollar had to depreciate 25 percent in real terms. It remains highly questionable whether exchange rate policy should seek an immediate depreciation of 25 percent, or indeed any immediate depreciation. With the U.S. production relatively close to capacity, and with some evidence of increased inflationary pressures, monetary policy has appropriately been tightened. The effect has probably been to strengthen the dollar in foreign-exchange markets. An effort to drive the dollar down by easing of monetary policy would be a mistake so long as the threat of resurgence of inflation remains serious. An effort to drive the dollar down through other means (except possibly a tightening of fiscal policy) could also be counterproductive. It could easily contribute to inflationary pressures that would lead to further monetary tightening. Thus, even if longer-run considerations suggest a substantially lower dollar, it may not be desirable to move in that direction immediately.

Conversely, suppose that we knew that the dollar was now at its long-run equilibrium value. Suppose further that the Federal Reserve has overdone its monetary tightening, and the U.S. economy is about to fall into recession (with other industrial nations continuing to expand). In a recession, U.S. interest rates are likely to fall substantially unless this is vigorously resisted by the Federal Reserve. Lower U.S. interest rates probably mean sharp declines in the dollar. In this recession scenario, it would not make sense to tighten monetary policy in order to hold the exchange rate. Other efforts at exchange rate management might well prove ineffective. Thus, it is not difficult to conceive of situations in which the desirable policy is to allow an exchange rate to move away from its long-run equilibrium value.

Another reason for caution in policies of exchange rate management is that we really don't know what represents a sustainable level of the current account balance in the medium term. Paul touches on this point early in his paper, but I believe that it deserves more emphasis. Suppose that we have already seen most of the favorable effect on the U.S. trade balance of dollar depreciation since early 1985. Suppose further that the U.S. will grow at about the same rate as other industrial countries and that conventional estimates of income and relative price elasticities of exports and imports are correct. If the United States needs to achieve a zero current account balance by the middle 1990 s, then the standard calculations indicate the need for a substantial (20 to 30 percent) 
further decline in the real foreign exchange value of the dollar. However, if the United States and the rest of the world can live with a U.S. current account deficit of 1.5 percent of U.S. GNP (one-half of the current level), then the implied magnitude of required dollar depreciation under the standard assumptions is cut in half. A measured current account deficit of 1.5 percent of GNP might correspond to an actual deficit of only 1 percent of GNP. With such a deficit in the middle 1990s, the ratio of U.S. net external liabilities to U.S. GNP would stabilize at around 15 to 20 percent, well below the ratios for a number of other industrial countries. Thus, a measured current account deficit equal to 1.5 percent of GNP is not a totally unreasonable assumption on which to base estimates of the need for further exchange rate adjustment.

If further significant improvement in the U.S. trade balance is still in the pipeline from past dollar depreciation, then little further depreciation may be needed to reach a current account deficit equal to 1.5 percent of U.S. GNP. More improvement still in the pipeline means not only less work to be done by further depreciation, it also means that relative price elasticities are probably larger than previous estimates and, hence, more effectiveness from each unit of depreciation. Pushing on all of these fronts, taking account of the many excellent points in Paul's paper, it is possible to construct a plausible case that no further real depreciation of the dollar may be needed to reach a sustainable current account position in the medium term.

This possibility, and the analysis that underlies it, justifies the caution that Paul urges in giving advice to policymakers about "where we go from here", with respect to the foreign-exchange value of the dollar. However, I would also emphasize that, allowing for substantial uncertainty, the best available evidence still points to the likely need for some further real dollar depreciation in the medium term. By making this point, with suitable cautions and qualifications, we may help to guard against the danger that a "don't know", response to the question of where the exchange rate needs to move will be used to justify a policy of pegging the exchange rate where it is now. For exchange rate policy, I believe that the most important conclusion is Paul Krugman's final conclusion, "in the medium term ... exchange rate changes [are] an essential part of the adjustment process.",

\section{Reference}

Mussa, M. 1986. The nominal exchange rate regime and the behavior of real exchange rates. Carnegie-Rochester Conference Series, v. 25, ed. Karl Brunner and Allan Meltzer, 117-213. Amsterdam: North-Holland. 
This Page Intentionally Left Blank 